\title{
Measures and technical means for increasing efficiency and reliability of extra high voltage transmission lines
}

\begin{abstract}
Electromagnetic transients are considered in the implementation of three-phase automatic reclose on the transmission line of extra high voltage $750 \mathrm{kV}$. The influence of automatic shunting of phases and pre-insertion active resistance for limiting the characteristics of the aperiodic component of the current, which obstructs the transition of full current through zero, is evaluated. The paper analyses measures taking into account the effect of changing the degree of compensation of charging power and the angles of switching on an SF6 circuit breaker. Sub-schemes of disconnected undamaged phases of the extra high voltage transmission line for the investigation of the aperiodic current component have been developed. The values of the pre-insertion active resistances of different connection and automatic shunting of the phases are determined at which there is an effective reduction of the characteristics of the aperiodic component of the current. In the software environment, a model was developed and switching transient processes were simulated in the $750 \mathrm{kV}$ transmission line. Operating modes that are potentially dangerous for SF6 circuit breakers are determined and recommendations are given to avoid them. Currently the technical and economic requirements for power transmission lines designed for the transport of electricity from large power plants and for the communication of powerful energy systems are increasing. Today there is importance of reducing specific investment in the construction of new and reconstruction of existing lines. The solution to these issues is associated with the maximum use of power lines by increasing their power transfer capability and controlling modes, especially in operating emergency conditions and post-emergency operation of power systems.
\end{abstract}

Streszczenie. Stany przejściowe elektromagnetyczne są brane pod uwage przy wdrażaniu trójfazowego automatycznego ponownego zamykania na linii przesyłowej bardzo wysokiego napięcia $750 \mathrm{kV}$. W pracy wpływ automatycznego bocznikowania faz i rezystancji wstępnej w celu ograniczenia charakterystyki aperiodycznego składnika prądu, który utrudnia przejście pełnego prądu przez zero. W pracy przeanalizowano parametry uwzględniające wpływ zmiany stopnia kompensacji mocy ładowania i kątów włączenia wyłącznika SF6. W środowisku oprogramowania opracowano model $i$ symulowano procesy przejściowe w linii przesyłowej 750 kV. (Techniki zwiększania skuteczności i niezawodności linii wysokiego napięcia $750 \mathrm{kV}$ )

Keywords: electromagnetic transients, automatic phase shunting, three-phase automatic reclose, aperiodic component of current.

Słowa kluczowe: zjawiska elektromagnetyczne, linie bardzo wysokiego napięcia, procesy załączania

\section{Introduction}

Due to the modernization of the switching equipment replacement of air circuit breakers on SF6 circuit breakers in the bulk electrical networks, there was a need to analyze the switching transients in $750 \mathrm{kV}$ extra high voltage transmission lines. Due to the lacks of experience in operating SF6 circuit breakers at $750 \mathrm{kV}$ extra high voltage (EHV) substations, accidents have occurred which have significantly reduced the reliability of the operation of bulk electrical networks [1-6]. One of the typical examples of switching that causes damage of SF6 switch is the fast on/off cycle [1-3]. On the other hand, the reliability is one of the most crucial subjects of power and electrical energy systems [7-9].

Such a typical switching example is the cycle of a threephase automatic recloses (TPAR) in the event of a nonliquidated metal short circuit in one of the phases. In case of unsuccessful TPAR, the damaged phase is switched on to the non-liquidated short circuit and the damaged phases are switched-off. After switching on the non-damaged phases, there may be an aperiodic current component $i_{a c c}$ (ACC) with characteristics values are significantly higher than the maximum permissible passport data of the SF6. Exceeding the value $i_{a c c}$ and duration $T_{a p}$ of the ACC leads to a delay in the transition due to zero full transient current fig. 1. A durable damping process $i_{a c c}$ with a value exceeding the maximum allowed prevents the full current from passing through zero, resulting in damage to the gas switch chamber. According to the requirements specified in [10], the ACC value may not exceed $58 \%$.

It is assumed that when the switch is off, arc extinguishing occurs in each phase at the moment when the current passes through a zero value. Since the dispersion in the action of the poles of a SF6 circuit breaker when switched on does not exceed $0.001 \mathrm{~s}$, the contacts are simultaneously closed. So, in the case of an unsuccessful TPAR, when the arc on the overhead line during the TPAR pause did not go out, it is possible to significantly delay the process of arc extinction [1-3].

A significant aperiodic component in the switching currents occurs not only with whole groups of shunt reactors. As a result of a series of transient calculations, the most unfavorable moments of contact closure after a TPAR pause and the moments of disconnection of an uncorrected failure by the value of the aperiodic component were found.

The objective of this work is to identify the conditions for the appearance of an aperiodic component in the current, to analyze the process of damping it using pre-insertion resistors, and also to analyze alternative solutions to the problem as a whole.

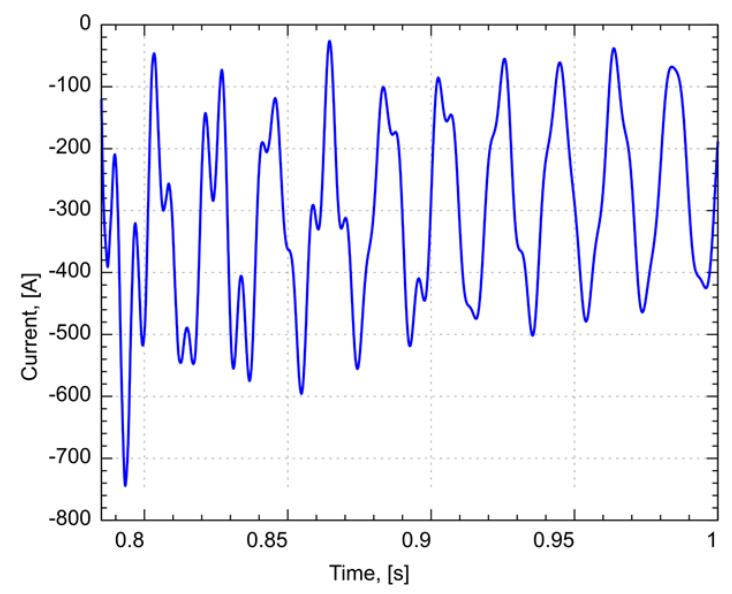

Fig. 1 Total transient current 
The reason for the appearance of the aperiodic component of the current during switching

In studies [2, 10-13], the simultaneous influence of the above measures on the significance of the ACC characteristics was not considered. The studies analyzed the effect of pre-insertion active resistances on the gas switch on magnetization currents and resonant overvoltages when switching on the EHV power line to the unloaded autotransformer. There are also studies [14,15] devoted to the estimation of the influence of pre-insertion active resistances and the moment of switching on the value of the characteristics of the ACC without analyzing the effect of changing the degree of compensation of the charging power of the line.

It should be noted that there are known works on the use of automatic phase shunting (APS) during single phase automatic re-closure (SPAR) to compensate for the recharge arc and elimination of abnormal resonance overvoltages [15-23]. Studies on the evaluation of the effects of ASF when performing the TPAR are also given. There are also no studies to compare the different types of connection of pre-insertion active resistors to the values of the characteristics of the $A C$ current. As shown by previous studies, the application of only reducing the degree of charge power compensation and the use of controlled switching do not always effectively reduce the ACC $[1-3,10,11]$

This paper deals with the switching of switching on of the low-voltage transmission line to short-circuit one of the phases, which leads to the activation of TPAR. Studies have shown that the changes in the switching angle of the gas switch and the change in the degree of compensation of the charging power of the low voltage transmission line cannot effectively reduce the aperiodic component to the passport values [24, 25].

The total current value in the switch $i_{C}(t)$ is determined by the expression:

$$
i_{C}(t)=i_{\text {inv }}(t)+i_{\text {ap }}(t)+i_{\text {osc }}(t)
$$

where $i_{i n v}=I_{\text {inv }} \cos (\omega t+\alpha-\Psi)$ is involuntary component current in circuit breaker; $\omega$ is angular velocity; $\alpha$ is moment of commutation; $I_{i n v}$ and $\Psi$ is amplitude and phase of involuntary value of current; $i_{a p}(t)=I_{a p} \sin (\alpha-\phi) \mathrm{e}^{-t / \tau} \quad \mathrm{i}$ is aperiodical component in circuit breaker; $I_{a p}$ is amplitude of aperiodical component; $t$ is time of electromagnetic transient; $\tau$ is the damping constant of the ACC; $i_{o s c}(t)=I_{t r} \mathrm{e}^{-\mathrm{t} / \tau_{\text {osc }}} \cos \left(\omega t+\alpha-\Psi_{t r}\right)$ is decaying current transient component in circuit breaker. $I_{t r}$ and $\Psi_{t r}$ is amplitude and phase of decaying transient component; $\tau_{o s c}$ is the damping constant of decaying current transient component.

The initial value of the aperiodic component of the current depends on the moment the circuit breaker closes (for example, if the switch-on occurs when the instantaneous value of the mains voltage is close to zero, then the aperiodic component has the largest value equal to the amplitude of the periodic component of the current). The damping time constant of the aperiodic current is determined by the ratio of the active and inductive resistances in its circuit.

The aperiodic time constant of the aperiodic component depends on the ratio of the inductance and resistance of the circuit:

$$
\tau=\frac{L_{\Sigma}}{R_{\Sigma}}
$$

where $L_{\Sigma}$ is equivalent inductance of an equivalent circuit: $R_{\Sigma}$ is equivalent resistance of the equivalent circuit.

So, the initial value of the ACC current component depends of values (1). On Fig. 2 are shown AP in phase A in cycle of TPAR. The permissible value of ACC component for SF6 circuit breakers $750 \mathrm{kV}$ is $58 \%$ of total current at the transition process.

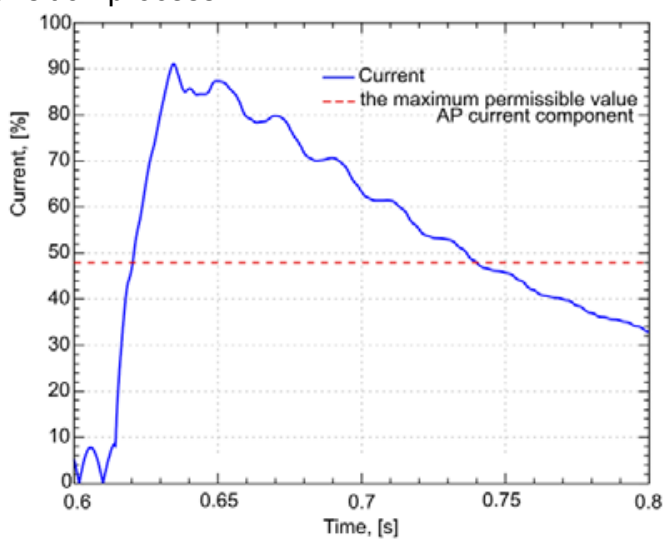

Fig. 2 Excess of ACC component the maximum permissible value

Measures and technical means of improving the reliability and efficiency of EHV power transmission lines due to switching

The main task of existing measures and means used in extra high voltage power transmission lines is to increase the reliability and operational efficiency of the operating modes of the main electric networks that they form. There are innumerable modes of operation of power lines, especially for operational normal operating modes. Normal modes of electrical networks mean those that allow longterm operation without any restrictions for both consumers and equipment of the networks themselves. But when critical deviations of values of parameters of an electric network are reached, it is necessary to speak already about occurrence of an abnormal mode for which use of traditional methods the controls will be inadequate and therefore ineffective. The consequences of uncontrolled abnormal mode can be not only the deterioration of the technical and economic performance electrical network, but also damage to the equipment of responsible consumers, as well as failure of the main equipment of the network itself with the further development of a system crash.

It should be noted that classification of abnormal modes, which occur in the abnormal nonsinusoidal and nonsymmetrical modes of extra high voltage power lines is given in [15-22]. The use of the term of abnormal mode is not accidental, because when working out literary sources $[1-6,10-13]$ and studies of experimental results [15-17,1922], it was concluded that this kind of modes is fundamentally different from traditional ones. The difference and the special characteristics of mode is that they are caused by an abnormal regime, primarily due to the effect of the source of distortion. In [18, 19, 25,26], the division of this type of mode into two main categories, depending on the resonance at a certain frequency, is shown on the basic harmonic and higher harmonic components.

Also, this developed classification of abnormal modes includes the considered form of the TPAR operation mode. An abnormal mode of operation exists during the implementation of the TPAR cycle and until the breaker is possibly damaged.

In extra high voltage power lines, the following measures and technical measures apply, shown Fig. 3:

- $\quad$ the use of pre-insertion resistances in SF6 circuit breakers, which can be connected in series or in parallel Fig. $3 \mathrm{a}$ ) and b);

- applications of automatic phase shunting when a phase disconnected is shunted by circuit breakers Fig. $3 \mathrm{c}$ );

- the controlled switching to ensure switching moments at the required time Fig. $3 \mathrm{~d}$ ); 
- disconnecting of groups of shunt reactors, as well as the use of open-phase modes of groups shunt reactors Fig. $3 \mathrm{f}$ ).

At Fig. $3 L_{M}, L_{E}-$ inductance of the shunt reactor which compensate capacitance between phases and Capacitance between phase and earth; $L_{L}, L_{R}$ - inductance and active resistance of the transmission line; $L_{S 1}, L_{S 2}, R_{1}, R_{2}-$ equivalent inductance and active resistance of systems; $R_{\text {pre }}$ - active pre-insertion resistance of SF6 circuit breaker.

On Fig. 3 a, b) $Q_{1}$ indicates the opened main contacts of the SF6 circuit breaker and $Q_{2}$ denotes the auxiliary circuit breaker of the pre-insertion active resistance, which are closed to reduce the effect of the aperiodic current component.

On Fig. $3 \mathrm{c}$ ), $Q_{1}$ denotes the open main contacts of the SF6 circuit breaker and $Q_{2}$ denotes the auxiliary contacts of the automatic phase shunting device for phase closure.

On Fig. $3 \mathrm{~d}$ ), $Q_{l}$ denotes a circuit breaker with a controlled switching device is designated for switching at an exact time.

On Fig. 3 f), $Q_{l}$ denotes the line phase power switch and $Q_{2}$ shows the switch of the shunt reactor for the case of studying the influence of the open-phase operation mode of the line on the aperiodic current component.

In Fig. 3 also indicates a short circuit that occurs on an extra high voltage overhead power line.

a)

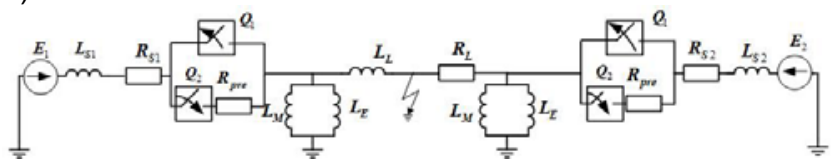

b)

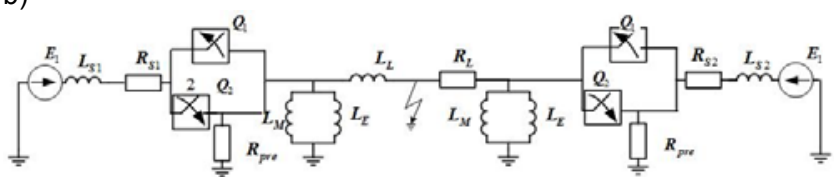

c)

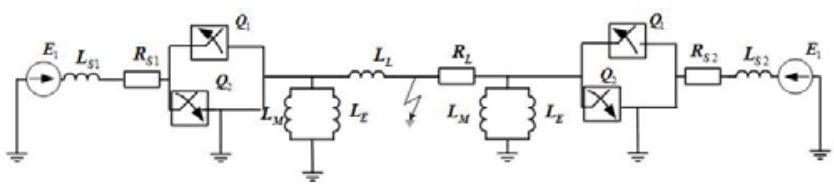

d)

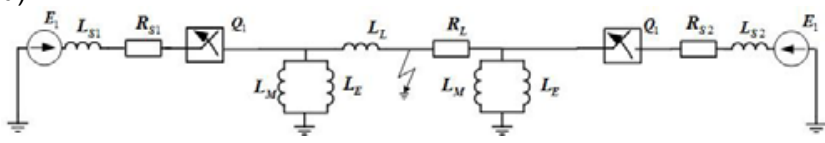

f)

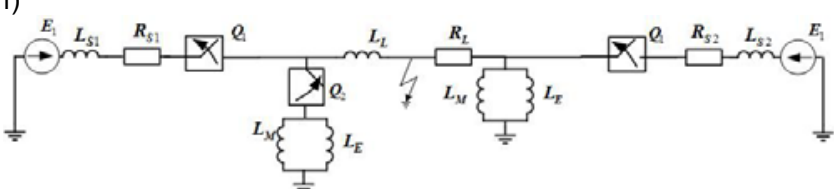

Fig. 3 Equivalent circuits of phase extra high voltage transmission line

The aperiodic time constant of the aperiodic component in case of application pre-insertion connected in series:

(3) $\tau=\frac{A B\left(R_{\text {pre }}^{2}(2 M+I)+2 R_{\text {pre }} A+2 R_{\text {pre }}\left(F R_{S 1}+G R_{S 2}\right)\right.}{C\left(R_{p r e}+R_{S 1}\right)\left(R_{p r e}+R_{S 2}\right)\left(A K+L_{S 1} L_{S 2}\left(L_{L} L_{M}+L_{L} L_{Z}+L_{Z} L_{M}\right)\right)}$

where $A=L_{L} L_{M} L_{E} ; B=L_{S 1} L_{S 2} ; C=R_{L} R_{M} R_{E} ; D=R_{S I} R_{S 2}$; $E=R_{S I}+R_{S 2} ; F=R_{L} R_{M} ; G=R_{L} R_{E} ; I=R_{M} R_{E} ; K=L_{S I}+L_{S 2} ;$ $M=F+G$.

The aperiodic time constant of the aperiodic component in case of application pre-insertion resistors connected in parallel:
(4) $\tau=\frac{A B\left(R_{\text {pre-ins }} C E+R D(2 F+I)+2 C D\right)}{R_{\text {pre-ins }} C D\left(A\left(L_{S 1}+L_{S 2}\right)+L_{S 1} L_{S 2}\left(2 L_{L} L_{M}+2 L_{L} L_{Z}+L_{M} L_{Z}\right)\right.}$

The above measures have proven themselves well in suppressing and limiting the characteristics of abnormal resonant overvoltages in non-sinusoidal and asymmetric operating modes $[16-19,25,27,28]$. It should be noted that today there is no work to assess the impact of measures and means on the aperiodic component of the total transient current (1) and especially aperiodic time constant (2).

Switch with pre-insertion active resistor can be used to extinguish large multiple voltages on the second harmonic. As shown by research [25,27-29], overvoltages on the second harmonic can exist for a long time, so the decisive factor in determining the scattering energy is the time of the emergence of an abnormal regime with unloaded autotransformer.

The method described in the article solves the problem of putting the line under voltage, avoiding the danger of damage to electrical equipment by resonant overvoltages on the second harmonic. The use of pre-insertion resistors can reduce the amplitude and duration of this type of overvoltage. It is important to note that the decision to use pre-insertion resistors in each case must be supported by the results of mathematical analysis. Thus, the use of preinsertion resistances in SF6 circuit breakers has not been verified by influencing the characteristics of the aperiodic component. Initial transition conditions for each phase corresponding to the maximum and minimum of the sine wave voltage [27-3']:

$$
\begin{aligned}
& \delta^{A} \in[0 ; 90 ; 180 ; 270 ; 360] ; \\
& \delta^{B} \in[122 ; 212 ; 300] ; \\
& \delta^{C} \in[60 ; 150 ; 240 ; 330] .
\end{aligned}
$$

The objective of the ASP is to reduce the electrostatic as well as the electromagnetic components of the feed current in order to ensure a successful SPAR [31-34].

It should be noted that the paper considers the worst case when the voltage in the intact phases goes beyond zero and the case when the voltage reaches its maximum value. In the first case, such initial conditions of the electromagnetic switching transient cause the maximum initial value of the aperiodic component of the current. As shown by the damping study of the aperiodic component of the current is determined by the ratio of the circuit's active resistance to the total inductance $[1,2,3]$. According to the data, the damping process for certain lines continues to $0.003-0.04 \mathrm{~s}$. A controlled switching device for aperiodic suppression can be used in combination with the above.

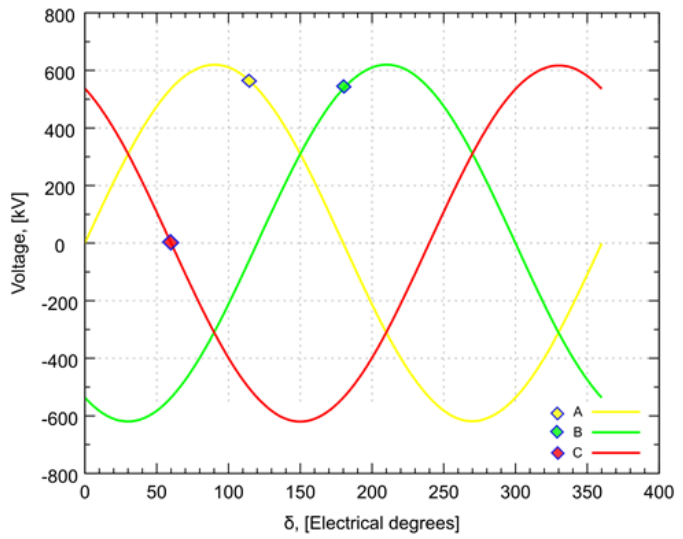

Fig. 4 Sine wave voltage phases A, B, C with designated switching points 
As we can see from (1) $i_{a p}(t)$ depends on $\alpha$ - moment of commutation. So we can that controlling switch device can reduce this two component. All circuit breakers are equipped controlled switching device Switch Sync F236. The sinusoid with possible moments of commutation is depicted on Fig. 4. To assess the impact of the switching moment on the characteristics of the aperiodic component, a simulation model is developed. The description of which is given in the next section.

When using controlled switching, the time constant will be equal to:

(6) $\tau=\frac{A B\left(G R_{M}\left(R_{S 1}+R_{S 2}\right) D(2 F+2 G+I)\right)}{D F R_{Z}\left(A K+B\left(2 L_{M} L_{Z}+2 L_{L} L_{Z}+L_{M} L_{Z}\right)\left(L_{S 1}+L_{S 2}\right)+L_{S 1} L_{S 2}\left(2 L_{L}\left(L_{M}+L_{Z}\right)+L_{M} L_{Z}\right)\right.}$

In case of switching-off the SR group, the decay time constant will be:

(7) $\tau=\frac{A B\left(G R_{M}\left(R_{S 1}+R_{S 2}\right) D(F+G+I)\right)}{D F R_{Z}\left(A K+B\left(L_{M} L_{Z}+L_{L} L_{Z}+L_{M} L_{Z}\right)\left(L_{S 1}+L_{S 2}\right)+L_{S} L_{S 2}\left(L_{L} L\right.\right.}$

(7) $\tau=\frac{D_{Z}\left(A K+B\left(L_{M} L_{Z}+L_{L} L_{Z}+L_{M} L_{Z}\right)\left(L_{S 1}+L_{S 2}\right)+L_{S 1} L_{S 2}\left(L_{L} L_{M}+L_{L} L_{Z}+L_{M} L_{Z}\right)\right.}{D_{2}}$

In case of application APS decay time constant will be:

$$
\tau=\frac{L_{S 1} L_{S 2}\left(R_{S 1}+R_{S 2}\right)}{R_{S 1} R_{S 2}\left(L_{S 1}+L_{S 2}\right)}
$$

To perform the time constant calculations, the following extra high voltage power line data were adopted. for the next lines Khmelnytsky Nuclear Power Plant (Ukraine) Rzeszow (Poland), South-Ukrainian nuclear power plant (Ukraine) - Isaccea (Romania), Western Ukrainian (Ukraine) - Albertirsa (Hungary). The resistance is $R_{\text {pre- }}$ ins $=400$ Ohms for both cases Fig. 3 a) and Fig. 3 b). In Table 1 are shown parameters of equivalent systems and shunt reactors.

Table 1. Parameters of systems and shunt reactors

\begin{tabular}{|c|c|c|c|c|c|}
\hline \multicolumn{2}{|c|}{ Impedance of system Z, Ohms } & \multicolumn{4}{|c|}{ Parameters of shunt reactor } \\
\hline $\begin{array}{c}\text { Khmelnytsky } \\
\text { Nuclear Power } \\
\text { Plant (Ukraine) }\end{array}$ & $\begin{array}{c}\text { Rzeszow } \\
\text { (Poland) }\end{array}$ & \multirow{4}{*}{$\begin{array}{l}L_{M} \\
{[\mathrm{H}]}\end{array}$} & \multirow{4}{*}{$\begin{array}{c}L_{E} \\
{[\mathrm{H}]}\end{array}$} & \multirow{4}{*}{$\begin{array}{l}R_{M} \\
{[\Omega]}\end{array}$} & \multirow{4}{*}{$\begin{array}{l}R_{E} \\
{[\Omega]}\end{array}$} \\
\hline $6.28+95.85 i$ & $4.78+60.85 i$ & & & & \\
\hline $\begin{array}{c}\text { South- } \\
\text { Ukrainian } \\
\text { nuclear power } \\
\text { plant (Ukraine) }\end{array}$ & $\begin{array}{c}\text { Isaccea } \\
\text { (Romania) }\end{array}$ & & & & \\
\hline $6.88+77.65 i$ & $6.78+88.48 \mathrm{i}$ & & & & \\
\hline $\begin{array}{l}\text { Western } \\
\text { Ukrainian } \\
\text { (Ukraine) }\end{array}$ & $\begin{array}{c}\text { Albertshire } \\
\text { (Hungary) }\end{array}$ & \multirow[t]{2}{*}{37.17} & \multirow[t]{2}{*}{9.42} & \multirow[t]{2}{*}{30} & \multirow[t]{2}{*}{13.44} \\
\hline $9.28+82.88 \mathrm{i}$ & $8.78+68.75 i$ & & & & \\
\hline
\end{tabular}

The calculations of the aperiodic time constant according to the expressions (3), (4), (6), (7), (8) are given in Table 2.

As can be seen from the results in Table 2, the lowest constant time value is observed when using controlled switching. In the case of ASP, the lowest value will be observed, which will lead to the longest running of the aperiodic component.

Table 2. Results of calculation of aperiodic time constant

\begin{tabular}{|c|c|c|c|}
\hline \multirow{2}{*}{$\begin{array}{c}\text { The name of } \\
\text { case }\end{array}$} & $\begin{array}{c}\text { Khmelnytsky } \\
\text { Nuclear Power } \\
\text { Plant (Ukraine) } \\
\text { - Rzeszow } \\
\text { (Poland) }\end{array}$ & $\begin{array}{c}\text { South- } \\
\text { Ukrainian } \\
\text { nuclear power } \\
\text { plant (Ukraine) } \\
\text { - Isaccea } \\
\text { (Romania) }\end{array}$ & $\begin{array}{c}\text { Western } \\
\text { Ukrainian } \\
\text { (Ukraine) } \\
\text { Albertirsa } \\
\text { (Hungary) }\end{array}$ \\
\hline $\begin{array}{c}\text { Without } \\
\text { measure }\end{array}$ & 0.097 & 0.098 & 0.1 \\
\hline $\begin{array}{c}\text { Pre-insertion } \\
\text { 'resistors in } \\
\text { series }\end{array}$ & 0.055 & 0.052 & 0.051 \\
\hline $\begin{array}{c}\text { Pre-insertion } \\
\text { resistors in } \\
\text { parallel }\end{array}$ & 0.093 & 0.095 & 0.098 \\
\hline $\begin{array}{c}\text { Automatic } \\
\text { shunting of } \\
\text { phase }\end{array}$ & 0.044 & 0.047 & 0.048 \\
\hline $\begin{array}{c}\text { Switching-off } \\
\text { the SR } \\
\text { group }\end{array}$ & 0.088 & 0.086 & 0.087 \\
\hline $\begin{array}{c}\text { Controlled } \\
\text { switching } \\
\text { device }\end{array}$ & 2.1 & 2.02 & 2.5 \\
\hline \multicolumn{2}{|c|}{} & & \\
\hline
\end{tabular}

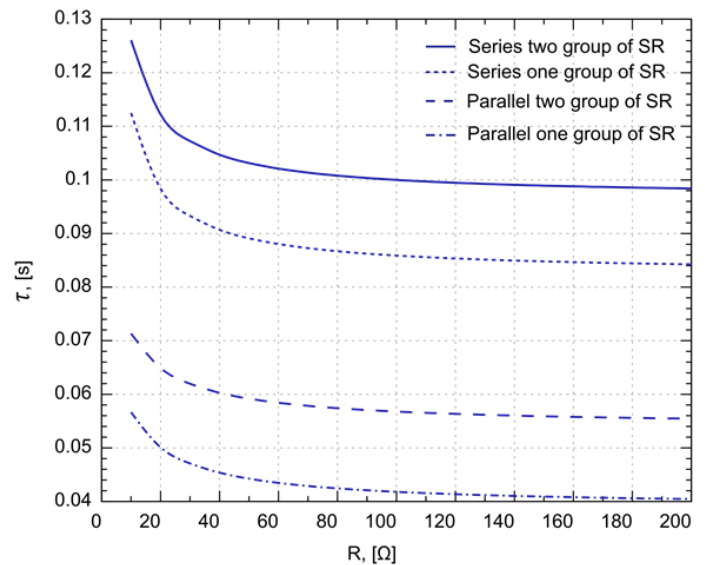

Fig. 5 Reducing the aperiodic time constant at different measures and means

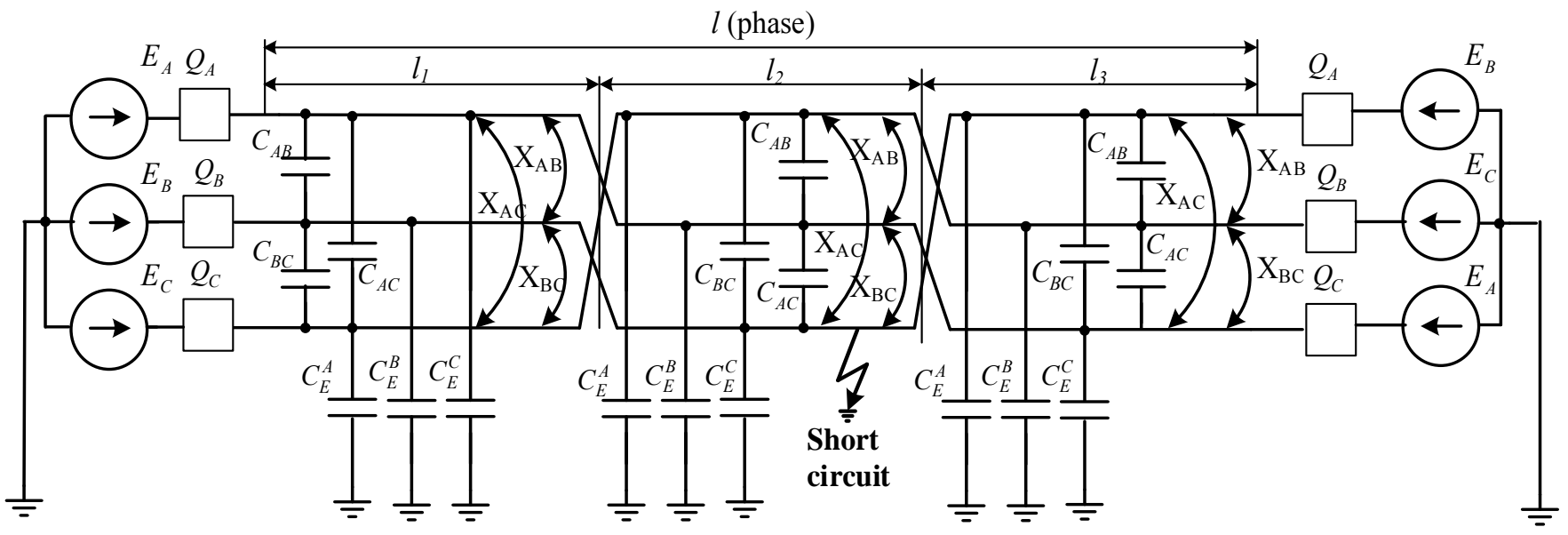

Fig. 6. Equivalent scheme for replacement of ultra-high voltage power line 
For example, in $[1-6,10-13]$ it is recommended to disable the shunt reactor group to reduce the characteristics of the aperiodic component. As you can see from the results, such an event reduces the time constant thereby increasing the duration of the transient. In fact, shutting down the bypass reactor group is ineffective. To test the efficiency, the results of which are shown in Fig. 5 were carried out.

As can be seen from Fig. 5, the use of shutdown of the shunt reactor group does not lead to a significant change in the time constant, while further dragging on the value of the impedance resistance does not lead to the required increase in the time constant.

In order to verify the correctness of the formulas and theoretical statements, a simulation model was developed for the analysis of electromagnetic transients in the TPAR cycle.

To study the electromagnetic transients, the following equivalent circuit of the transmission line replacement was used (Fig. 6), Which takes into account the real cycle of transposition. EMF was taken into account for each phase of the ultra-high voltage power transmission line. The single-phase metal short circuit was modeled in the middle of the line phase.

In Fig. 6 the following designations are introduced: $C_{E}^{A}, C_{E}^{B}, C_{E}^{C}$ are capacitances between the phase of the line and ground, $X_{A B}, X_{B C}, X_{A C}$ are interphase inductors, $C_{A B}, C_{B C}, C_{A C}$ are interphase capacitors, $E_{A}, E_{B}, E_{C}$ are EMF of phase, $Q_{A}, Q_{B}, Q_{C}$ are SF6 circuit breakers, $l_{1}, l_{2}, l_{3}$ are lengths of sections of transposition steps, $l$ are length of line.

The list of EHV lines for which research was conducted is listed on Table 2.

Table 2. The list of EHV lines of Integrated electrical power system

\begin{tabular}{|c|c|c|}
\hline № & The name of the line & Length, km \\
\hline 1 & Khmelnitsky NPP-Rzeszow (Poland) & 396 \\
\hline 2 & South Ukrainian NPP - Isaccea (Romania) & 403 \\
\hline 3 & Kievska Substation - Rivne NPP & 353 \\
\hline 4 & Zaporizhzhya NPP - Kakhovka Substation & 190 \\
\hline 5 & $\begin{array}{c}\text { Substation Western Ukraine - Albertirsa } \\
\text { (Hungary) }\end{array}$ & 479 \\
\hline 6 & Zaporizhzhya NPP - Dniprovska Substatio & 137 \\
\hline 7 & Zaporizhzhya NPP - Dniprovska Substation & 211 \\
\hline 8 & Substation West-Ukrainian - Rivne NPP & 282 \\
\hline 9 & $\begin{array}{c}\text { Substation Pivdennodonbaska - Substation } \\
\text { Donbass }\end{array}$ & 220 \\
\hline 10 & $\begin{array}{c}\text { Zaporizhzhya NPP - Substation } \\
\text { Pivdennodonbaska }\end{array}$ & 150 \\
\hline 11 & $\begin{array}{c}\text { Substation Dniprovska - South Ukrainian } \\
\text { NPP }\end{array}$ & 333 \\
\hline 12 & $\begin{array}{c}\text { Substation Zaporizhzhya - KuTES } \\
\text { substation }\end{array}$ & 323 \\
\hline 13 & Substation Western Ukraine - PS Vinnytsia & 361 \\
\hline 14 & CHAES - Khmelnitsky NPP & 136 \\
\hline 15 & $\begin{array}{c}\text { Substation West Ukrainian - Substation } \\
\text { Vinnitsa }\end{array}$ & 177 \\
\hline 16 & Substation North Ukrainian - Kursk NPP & 228 \\
\hline 17 & Vinnitsa - South Ukrainian NPP & 304 \\
\hline 18 & $\begin{array}{c}\text { Substation West Ukrainian - Khmelnitsky } \\
\text { NPP }\end{array}$ & 190 \\
\hline 19 & Substation Vinnitsa - South Ukrainian NPP & 126 \\
\hline
\end{tabular}

In order to verify the correctness of the formulas and theoretical statements, a simulation model was developed for the analysis of electromagnetic transients in the TPAR cycle.
Modelling of cycle three phase auto-reclose of extra high voltage transmission line

The model was developed to study the processes at single phase auto-reclose in the environment MATLAB/Simulink which are illustrated on Fig. 7. There were made calculations to find the effective measure to prevent this kind of overvoltages.

The three phase power system is simulated by voltage sources with fixed voltage and inductance. The overhead line is simulated by two parts, which are given complex matrices with distributed elements or values on the forward and reverse sequence.

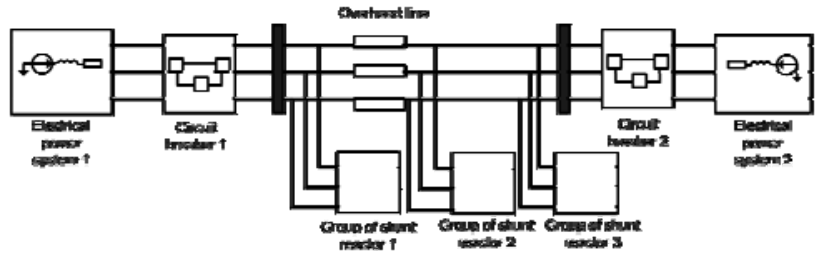

Fig. 7 Model of extra high voltage transmission line

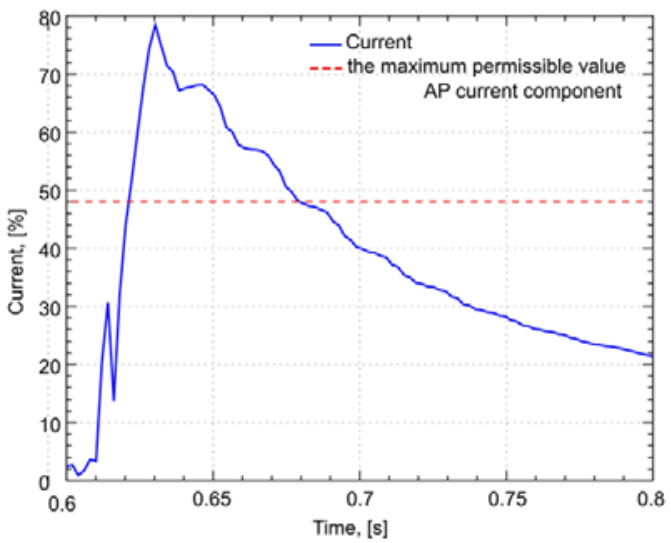

Fig. 8 Pre-insertion resistors connected in series

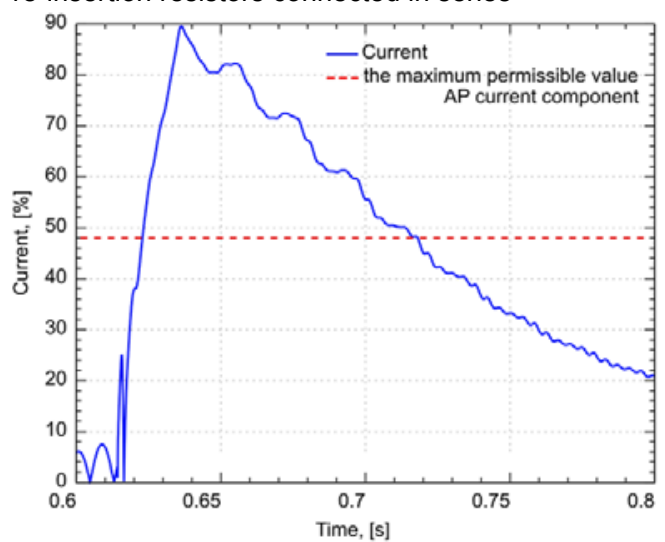

Fig. 9 Pre-insertion resistors connected in parallel

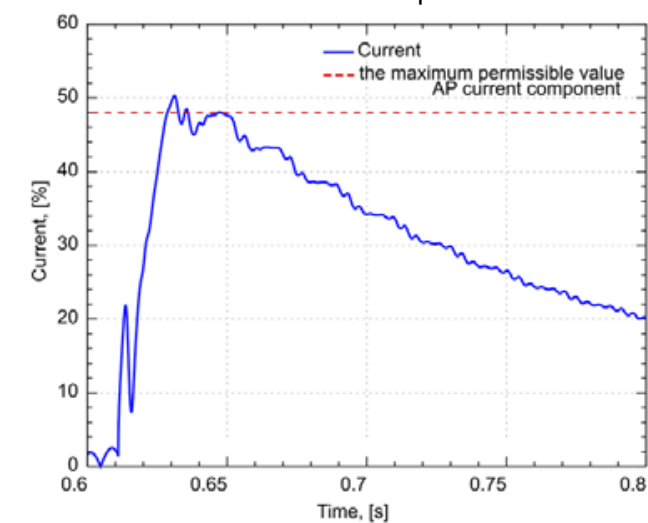

Fig. 10 Controlled switching device 


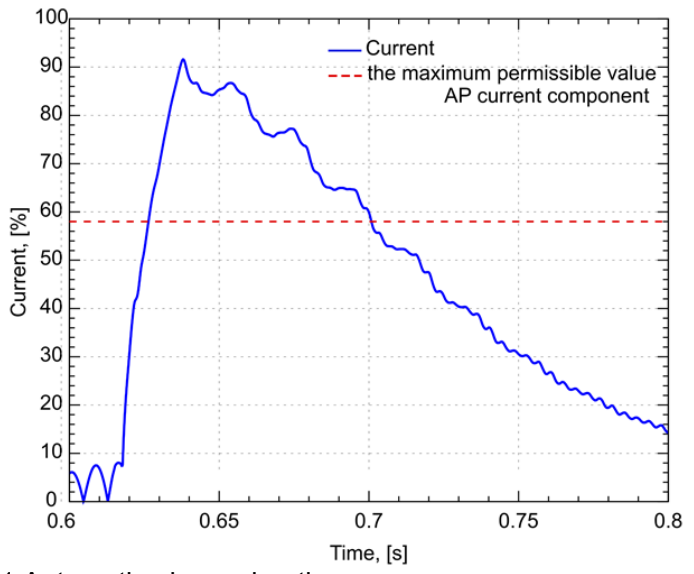

Fig. 11 Automatic phase shunting

Using the data in Table 1, we simulate extra high voltage line modes using a specific measure and technique. Each case is illustrated in Fig. 8-10.

As can be seen from Fig. 8-11, the simulation results confirm the theoretical assumptions about the duration of existence of the aperiodic component and the derived equations (3), (4), (6-8). The shortest duration of the aperiodic component is observed when using controlled switching (9). The highest duration is observed with the use of automatic phase shunting (10). The use of pre-insertions witched resistors also does not produce the required result (7-8).

\section{Conclusions}

1. When designing extra high voltage power lines, a careful analysis of the electromagnetic transients accompanying the switching during operation is necessary. Quick on-off cycles (symmetric or non-phase) should be avoided in case of TPAR. In particular, in such cases it is necessary to pay attention to the cycle of fast three-phase automatic reconnection, in which the switch may be damaged due to the aperiodic component of the current.

2. The results of the work confirm the theoretical principles, which consist in the inefficiency of using preinsertion resistances and automatic phase shunting to reduce the characteristics of the aperiodic component of the current of the total transient process. This also applies to the disconnection of a group of shunt reactors as measure. The derived formulas for the determination of the aperiodic time constant of the aperiodic component confirm the above. Changing the resistance value of the pre-insertion resistor when disconnecting the group of shunt reactors also confirmed the inefficiency of using the same means even when used together. This analysis was performed without any significant assumptions based on the mathematical models developed in MATLAB which confirm the theoretical propositions.

Authors: Doc., PhD., Vladislav Kuchanskyy, Institute of Electrodynamics of NAS of Ukraine, Kiev, Ukraine kuchanskiyvladislav@gmail.com;

PhD., Satyam Paul, Department of Engineering Design and Mathematics, University of the West of England, Bristol, United Kingdom satyam.paul@uwe.ac.uk;

Doc., PhD., Olena Rubanenko, Regional Innovational Center at the Faculty of Electrical Engineering University of West Bohemia, Plzen, Czech Republic, rubanenk@rice.zcu.cz;

PhD., Iryna Hunko, Department of Electric Stations and Systems, Vinnytsia National Technical University, Khmelnytsky highway 95, 21021, Vinnytsya, Ukraine iryna hunko@ukr.net;
REFERENCES

[1] Sawick A., Modified arc models in a SF6 power circuit breaker, Przegląd Elektrotechniczny, 1 (2018), 93-96

[2] Czaban A., Lis M., Chrzan M., Szafraniec A., Levoniuk V., Mathematical modelling of transient processes in power supply grid with distributed parameters, Przeglad elektrotechniczny, 2018, nr 5, 17-20.

[3] Machowski J., Kacejko P., Robak S., Miller P., Wancerz M., Analizysystemu elektroenergetycznego w średniookresowym planowaniurozwoju, Przegląd Elektrotechniczny, R. 89 (2013), nr 6, 234-237

[4] Flisowski, Z. Kosztaluk, R., Methods of overvoltage reduction in powernetworks, Przeglad Elektrotechniczny, v. 77 (2001), nr. 11, 267-271

[5] Chmielewski T., Oramus P., Florkowski M., Modeling of electric arc inanalysis of switching overvoltages during current interruption by LVelectromechanical relays, Przegląd Elektrotechniczny, 2016, nr. 2, 202-206

[6] Liang Ji, Booth C., Dyśko A., Kawano F., Beaumont P., Improved Fault Location Through Analysis of System Parameters During Autoreclose Operations on Transmission Lines, Power Delivery IEEE Transactions on, vol. 29 (2014), No. 6, 2430-2438

[7] A.-M. Hariri, H. Hashemi-Dezaki, and M. A. Hejazi, "A novel generalized analytical reliability assessment method of smart grids including renewable and non-renewable distributed generations and plug-in hybrid electric vehicles," Reliability Engineering \& System Safety, 2020, vol. 196, 1-17.

[8] H. Hashemi-Dezaki, A.-M. Hariri, and M. A. Hejazi, "Impacts of load modeling on generalized analytical reliability assessment of smart grid under various penetration levels of wind/solar/non-renewable distributed generations," Sustainable Energy, Grids and Networks, 2019, vol. 20, 1-16.

[9] H. Hashemi-Dezaki, H. Askarian-Abyaneh, A. Shams-Ansari, M. Dehghani Sanij, and M. A. Hejazi, "Direct cyber-power interdependencies-based reliability evaluation of smart grids including wind/solar/diesel distributed generations and plug-in hybrid electrical vehicles," International Journal of Electrical Power \& Energy Systems, vol. 93,1-14

[10] Sili Y.; Gang L.; PeiRen W.; Duifeng Y. ; Xiangxiang G. ; Yuan Y., Discussion on the Problem About Capacitive Current Switching of EHV and UHV AC Circuit Breaker, 2017 4th International Conference on Electric Power Equipment - Switching Technology (ICEPE-ST), 22-25

[11]Kachesov V., Kachesov D., Requirements for switching algorithms of EHV shunt compensated OHL by SF6 circuit breakers, Proceedings of International Conference on power systems Transients (IPST 2011) , Delft, Netherlands, 2011, 1518

[12]Naumkin I., Balabin M., Lavrushenko N., Naumkin R. Simulation of the $500 \mathrm{kV}$ SF6 circuit breaker cutoff process during the unsuccessful three-phase autoreclosing, Proceedings of International Conference on power systems Transients (IPST 2011), Delft, Netherlands, 2011, 5-11

[13]Jian H., Xiaofeng J., Xiaoguang H., Automated monitoring and analysis for high voltage circuit breaker, 2010 5th IEEE Conference on Industrial Electronics and Applications, Taichung, 2010, 560-564

[14]Gong R., Wang S., Luo X., Analysis and Design in Extra High Voltage Circuit Breakers Employing Shunted Capacitors, 2012 Sixth International Conference on Electromagnetic Field Problems and Applications, Dalian, Liaoning, 2012, 1-4

[15]Lazimov T., Saafan E., Babayeva N., Transitional processes at switching-off capacitor banks by circuit-breakers with pre-insertion resistors, 2015 Modern Electric Power Systems (MEPS), Wroclaw, 2015, 1-4

[16]Lazimov T., Imanov S., Saafan E., Transitional recovery voltages at capacitive currents switching-offs by vacuum and SF6 circuit-breakers, 2010 Modern Electric Power Systems, Wroclaw, 2010, 1-5

[17]Kuchanskyy V., Application of Controlled Shunt Reactors for Suppression Abnormal Resonance Overvoltages in Assymetric Modes, 2019 IEEE 6th International Conference on Energy Smart Systems (ESS), Kyiv, Ukraine, 2019, 122-125

[18] Kuchanskyy $V$., The prevention measure of resonance overvoltges in extra high voltage transmission lines, 2017 IEEE First Ukraine Conference on Electrical and Computer 
Engineering (UKRCON), Kiev, 2017, 436-441

[19]Tugay Y., The resonance overvoltages in EHV network, Proceedings of IEEE Sponsored Conference EPQU'09 International Conference on Electrical Power Quality and Utilisation, Poland, Lodz, 2009, 14-18.

[20]V. Kuznetsov, Y. Tugay and V. Kuchanskyy, "Investigation of transposition EHV transmission lines on abnormal overvoltages", Technical electrodynamics, 51-56, Nov. 2013.

[21]V. Kuznetsov, Y. Tugay and V. Kuchanskyy, Influence of corona discharge onthe internal ovevoltages in high way electrical networks", Technical electrodynamics, 5560, Nov. 2017

[22]Kuznetsov V., Tugay Y., Kuchanskyy V. Overvoltages in open-phase mode. Tekhnichna Elektrodynamika. No 2. pp.40-41.2012

[23] Kuchanskyy V., The application of controlled switching device for prevention resonance overvoltages in nonsinusoidal modes, 2017 IEEE 37th International Conference on Electronics and Nanotechnology (ELNANO), Kiev, 2017, 394399.

[24]Vladislav Kuchanskyy, Olena Rubanenko, Influence assesment of autotransformer remanent flux on resonance overvoltage UPB Scientific Bulletin, Series C: Electrical Engineering, 2020, 82(3):233-250.

[25] Live Tank Circuit Breakers. Buyer's Guide. ABB AB. 2014. $152 \mathrm{p}$.

[26]T. Orosz, Z. Á. Tamus and I. Vajda, "Modeling the high frequency behavior of the Rogowski-coil passive $\mathrm{L} / \mathrm{r}$ integrator current transducer with analytical and finite element method," 2014 49th International Universities Power Engineering Conference (UPEC), Cluj-Napoca, 2014, pp. 1-4, doi: 10.1109/UPEC.2014.6934663.

[27] Su C., Wang P., Liao C., Chou M., Analysis of harmonic overvoltages during transformer energization for mass rapid transit systems, 2016 10th International
Conference on Compatibility, Power Electronics and Power Engineering (CPE-POWERENG), Bydgoszcz, 2016,. 33-38

[28] Abdulsalam S., Xu W., A sequential phase energization method for transformer inrush current reduction-transient performance and practical considerations, IEEE Transactions on Power Delivery, 2007, vol. 22(1), 208-216

[29] Brunke J. H., Fröhlich K. J., Elimination of transformer inrush currents by controlled switching - part II: application and performance considerations, IEEE Transactions on Power Delivery, 2001, vol. 16(2), 281-285

[30] Cho C., Lee J., Min B., Application of controlled switching device for high voltage circuit breaker in KEPCO real power system, 2017 4th International Conference on Electric Power Equipment - Switching Technology (ICEPE-ST), Xi'an, 2017, 492-495

[31] Hasibar R., Legate A., Brunke J., Peterson W. The Application of HighSpeed Grounding Circuit breakers for Single-Pole Reclosing on $500 \mathrm{kV}$ Power Systems, IEEE Transactions on Power Apparatus and Systems, vol. PAS-100, No. 4, 1512-1515

[32] Baina H., Xin L., Jianyuan X., The Analysis of Secondary Arc Extinction Characteristics on UHV Transmission Lines, 2008 International Conference on High Voltage Engineering and Application, Chongqing, 2008, 516-519

[33]Mizoguchi H., Hioki I., Yokota T., Yamagata Y. Tanaka K., Development of an interrupting chamber for 1000 $\mathrm{kV}$ highspeed grounding circuit breakers, IEEE Transactions on Power Delivery, vol. 13, No. 2, 495-502

[34] Chi T., Xin L., Jianyuan X., Zhen-xin G., Comparison and Analysis on Very Fast Transient Overvoltage Based on 550kV GIS and 800kV GIS, 2008 International Conference on High Voltage Engineering and Application, Chongqing, 2008, 288-291. 